\title{
THE DEGREE OF COMMITMENT OF FACULTY MEMBERS IN THE COLLEGE OF EDUCATION IN DALAM TO TIME MANAGEMENT IN LIGHT OF DISTANCE TEACHING
}

\author{
O GRAU DE COMPROMISSO DOS MEMBROS DO FACULDADE NA FACULDADE DE EDUCAÇÃO \\ DE DALAM PARA A GESTÃO DO TEMPO À LUZ DO ENSINO A DISTÂNCIA
}
EL GRADO DE COMPROMISO DE LOS FACULTADES DEL COLEGIO DE EDUCACIÓN DE DALAM PARA LA GESTIÓN DEL TIEMPO EN LA DOCENCIA LIGERA A DISTANCIA

Thikryat Jibril Qaralleh ${ }^{1}$

\begin{abstract}
Abstract: The current study aimed to identify the degree of commitment of faculty members in the College of Education in Dalam to time management in light of distance teaching from the viewpoint of the college's students. To achieve the aim of the study, a questionnaire was developed consisting of (25) items and distributed to a sample of (20\%). The study leads to the following results: that the general arithmetic mean of the respondents 'answers to the paragraphs that measure the degree of commitment of the faculty members in the College of Education in Dalam to time management in the light of distance teaching reached (3.21) and represents an medium average grade and The absence of statistically significant differences at the level of significance $(\alpha \leq 0.05)$ in the degree of commitment of faculty members in the College of Education in Dalam to time management in light of distance teaching from the viewpoint of the college students female according to the two variables: (academic department and academic level). The study made several recommendations, including: Creating and developing distance learning platforms and encouraging faculty members to adhere to distance education.
\end{abstract}

Keywords: Time, Time management, Distance teaching.

Resumo: O presente estudo teve como objetivo identificar o grau de comprometimento dos docentes da Faculdade de Educação de Dalam com a gestão do tempo à luz do ensino a distância sob a ótica dos alunos da faculdade. Para atingir o objetivo do estudo, foi elaborado um questionário composto por (25) itens e distribuído a uma amostra de (20\%). O estudo leva aos seguintes resultados: que a média aritmética geral das respostas dos respondentes aos parágrafos que medem o grau de comprometimento dos docentes da Faculdade de Educação de Dalam com a gestão do tempo em função do ensino a distância alcançada $(3,21$ ) e representa uma nota média média e A ausência de diferenças estatisticamente significativas no nível de significância $(\alpha \leq 0,05)$ no grau de comprometimento dos docentes da Faculdade de Educação de Dalam com a gestão do tempo à luz do ensino a distância do ponto de vista dos universitários do sexo feminino de acordo

${ }^{1}$ Prince Sattam bin Abdulaziz University, AlKharj, Saudi Arabia. 
com as duas variáveis: (departamento acadêmico e nível acadêmico). O estudo fez várias recomendações, incluindo: Criar e desenvolver plataformas de ensino à distância e incentivar os docentes a aderir à educação a distância.

Palavras-chave: Tempo, Gestão do tempo, Ensino a distância.

Resumen: Resumen: El presente estudio tuvo como objetivo identificar el grado de compromiso de los profesores de la Facultad de Educación de Dalam con la gestión del tiempo a la luz de la enseñanza a distancia desde el punto de vista de los estudiantes de la facultad. Para lograr el objetivo del estudio, se desarrolló un cuestionario compuesto por (25) ítems y distribuido a una muestra de (20\%). El estudio arroja los siguientes resultados: que se alcanzó la media aritmética general de las respuestas de los encuestados a los párrafos que miden el grado de compromiso de los profesores de la Facultad de Educación de Dalam con la gestión del tiempo a la luz de la enseñanza a distancia $(3,21)$ y representa una nota media media y La ausencia de diferencias estadísticamente significativas en el nivel de significancia $(\alpha \leq 0.05)$ en el grado de compromiso de los profesores de la Facultad de Educación de Dalam con la gestión del tiempo a la luz de la enseñanza a distancia desde el punto de vista de los estudiantes universitarios mujeres según las dos variables: (departamento académico y nivel académico). El estudio hizo varias recomendaciones, que incluyen: Crear y desarrollar plataformas de aprendizaje a distancia y alentar a los miembros de la facultad a adherirse a la educación a distancia.

Palabras clave: Tiempo, Gestión del tiempo, Enseñanza a distancia.

\section{INTRODUCTION}

The time has a quite important role for organizations that play a significant role in modern human life, as well as in the sustainability and modernization process of human life (Çelebi, 2017). Time began to be perceived as a resource that must be managed by managers at the beginning of the 80s (Bülbül, 2014) Managers and employees of organizations must therefore be familiar with the characteristics of time in order to understand and manage it. As time is something that is given by God to all people equally, regardless of wealth, age or sex, it is a gift and a treasure. (Yurdagül, 2016), Time management skills are an essential component of college student success, especially in online(classes Baker,Evans\&Cung,2019) as well as for educational institutions, they benefit from technology in undertaking important roles in the social, cultural and economic growth and development of a nation \& Educational institutions are among the institutions that have been most affected by information technologies, and also amongst those which use these technologies most frequently. (Akar, 2018, pp.8), except the Loyd et al. (2012) identified four faculty-perceived barriers to online teaching : interpersonal, institutional, training and technology, and cost-benefit barriers. Faculty identified time management as a barrier, which fell into the theme of cost-benefit barriers , and(Beattie et al. 2017)It is considered that One critical challenge in online classes is time management, that time management is an important skill related to college performance in both 
face-to-face and online postsecondary classes. Poor time management and fewer study hours are the leading predictors of poor academic performance in a traditional 4-year college education setting.

Beattie et al. (2017) identified the numbers of hours spent studying as a critical factor related to academic performance in higher education. We measure students 'expected time commitment on our pre-course survey. Admittedly, expected time commitment could vary from actual time spent studying, but believing The question is about our expectationsis a reasonable proxy measure for actual time spent on the course. The two time management measures captured on the precourse survey, keeping record of deadlines and planning work in advance, are the most direct measures of time management available.

\section{LITERATURE REVIEW}

Bozbayindir (2019), The aim of this study is to review the relationship between the time management skills and cyberloafing behavior of school managers. Descriptive survey and relational research models were used in this research. Data was collected from 181 school managers at official elementary schools, secondary schools, and secondary education schools in the district of Nizip in Gaziantep during the 2017-2018 school year. A "Time Management Scale",The research concluded the better their time planning and effective use of time, the more their significant and insignificant cyberloafing behavior decreased.

Study Baker, Evans \& Cung(2019) aimed answer to Does Inducing Students to Schedule Lecture Watching in Online Classes Improve Their Academic Performance? An Experimental Analysis of a Time Management Intervention Through a randomized control trial of students in a for-credit online course at a public 4-year university, Results indicate the intervention had positive effects on initial achievement scores; students who were given the opportunity to schedule their lecture watching in advance scored about a third of a standard deviation better on the first quiz than students who were not given that opportunity. These effects are concentrated in students with the lowest self-reported time management skills.

Oyarzun, Martin, \& Pogue(2012) This study examined 256 faculty survey responses to determine perceptions of helpfulness of 24 time management strategies grouped into four 
categories defined by Berge (1995) as managerial, pedagogical, technical, and social. Findings indicate that establishing clear and specific expectations, was perceived as the most helpful, followed by organizing content into modules, which were both pedagogical time management strategies. Participants additionally responded to two open-ended items regarding the most and least helpful time management strategies. The open-ended responses were consistent with the survey findings. The relationship between faculty demographic factors and strategies showed that receiving training to teach online affected the faculty perceptions of technical time management strategies.

The study Van de Vord \&Pogue (2012), Teaching Time Investment: Does Online Really Take More Time than Face-to Face was designed to investigate which aspects, if any, are more time consuming for instructors teaching in the online environment. Time logs were kept by four online instructors (eight classes) and six on-campus instructors (six classes) through six weeks of the 15week semester. Results indicated that, overall, face-to-face teaching required more time per student, but certain aspects of online teaching take considerably more time per student than in the face-to-face classroom.

\subsection{The study problem}

An online instructor has unique challenges that differ from those of a face-to-face instructor, and time commitment has been acknowledged as one of those challenges that contribute to barriers to faculty adoption of online teaching, Therefore, this study presented that problem by answering the following questions:

1- What is The degree of commitment of faculty members in the College of Education in Dalam to time management in light of distance teaching from the viewpoint of college students female?

2- Are there statistically significant differences at the level of significance $(\alpha \leq 0.05)$ in the degree of commitment of the faculty members in the College of Education in Dalam to time management in light of distance teaching from the viewpoint of the college students female according to the academic department variable and the academic level? 


\subsection{Methodology and procedures}

Study methodology: To achieve its objectives, the study adopted a descriptive and fieldanalytical research methodology

\subsection{Study Population and Sample}

Consisted of all the students female of the College of Education in Dalam who studied through the distance learning system in the summer semester, and their total number is (215). The following table No. (1) shows the distribution of the study sample according to the two variables: the academic department and the academic level:

Table 1. Distribution of the study population according to two variables: the academic department and the academic level

\begin{tabular}{|l|l|l|l|}
\hline \multicolumn{2}{|l|}{ Variable } & $\begin{array}{l}\text { The } \\
\text { number }\end{array}$ & Percentage \% \\
\hline \multirow{2}{*}{ Academic section } & Department of Economics & 27 & 27.0 \\
\cline { 2 - 4 } & Mathematics department & 37 & 37.0 \\
\cline { 2 - 4 } & Department of Islamic Studies & 13 & 13.0 \\
\cline { 2 - 4 } & the department of Arabic language & 23 & 23.0 \\
\cline { 2 - 4 } & Total & 100 & 100.0 \\
\hline Academic level & level five & 21 & 21.0 \\
\cline { 2 - 4 } & Sixth level & 40 & 40.0 \\
\cline { 2 - 4 } & Seventh level & 39 & 39.0 \\
\cline { 2 - 4 } & Total & 100 & $\mathbf{1 0 0 . 0}$ \\
\hline
\end{tabular}

\subsection{Study tool}

The study tool is a questionnaire and it consists of two parts: The first part: It includes information expressing the characteristics of the study sample, according to the two variables: (the academic department and the academic level), and the second part: includes (25) paragraphs that measure the degree of commitment of faculty members in the College of Education In the case of 
time management in the light of distance teaching, the respondents 'answers to the paragraphs of the questionnaire were classified according to the five-dimensional Likert scale

\subsection{The validity and reliability of the study tool}

* To ensure the validity of the study tool, it was presented to a number of faculty referees who have expertise in the subject of the study, \& All opinions and proposals of the referees were taken into consideration.

* The reliability coefficient was extracted according to the Cronbach alpha equation to ensure internal consistency in its final form, And the value of the overall stability coefficient $(0.844)$ is considered high and indicates consistency and consistency between the paragraphs of the tool.

\subsection{Statistical treatment}

To answer the two questions of the study, descriptive and analytical statistical methods were used, using the statistical package (SPSS.20) and using the following statistical methods.

1. Frequencies and percentages to describe the characteristics of the study sample.

2. Arithmetic means and standard deviations to answer the first study question.

3. Analysis of binary variance (Tow Way Anova) to answer the second study question.

\section{RESULTS AND DISCUSSION}

3.1 Results related to the first question: What is the degree of commitment of faculty members in the College of Education in Dalam to time management in light of distance teaching?

Table 2. The arithmetic averages and standard deviations to identify the responses of the sample members to the paragraphs that measure the degree of commitment of the faculty members in the College of Education in Dalam to time management in light of distance teaching arranged in descending order

\begin{tabular}{|l|l|l|l|l|l|}
\hline $\begin{array}{l}\text { The } \\
\text { number }\end{array}$ & Paragraph & $\begin{array}{l}\text { Arithmeti } \\
\text { c mean }\end{array}$ & $\begin{array}{l}\text { Standard } \\
\text { deviatio } \\
n\end{array}$ & $\begin{array}{l}\text { Sorted } \\
\text { by } \\
\text { average }\end{array}$ & $\begin{array}{l}\text { Level by } \\
\text { average }\end{array}$ \\
\hline
\end{tabular}




\begin{tabular}{|c|c|c|c|c|c|}
\hline 8 & $\begin{array}{l}\text { Avoid using the phone while the } \\
\text { electronic lecture is taking place }\end{array}$ & 4.14 & 1.015 & 1 & High \\
\hline 1 & $\begin{array}{l}\text { Announcing to the students female } \\
\text { about the lecture through the } \\
\text { electronic system }\end{array}$ & 4.11 & 0.618 & 2 & High \\
\hline 19 & $\begin{array}{l}\text { Commitment to the deadline for } \\
\text { assigning homework grade } \\
\text { electronically }\end{array}$ & 4.02 & 0.841 & 3 & High \\
\hline 12 & $\begin{array}{l}\text { Inform students of exam dates } \\
\text { electronically }\end{array}$ & 4.01 & 1.030 & 4 & High \\
\hline 2 & $\begin{array}{l}\text { Commitment to reach the teaching } \\
\text { room in the virtual class on time }\end{array}$ & 3.89 & 0.875 & 5 & High \\
\hline 20 & $\begin{array}{l}\text { Take care, as much as possible, to } \\
\text { avoid wasting time during the } \\
\text { distance learning session }\end{array}$ & 3.81 & 1.061 & 6 & High \\
\hline 4 & $\begin{array}{l}\text { Preparing the objectives of the } \\
\text { course plan electronically so that it } \\
\text { can be presented to students }\end{array}$ & 3.75 & 0.936 & 7 & High \\
\hline 6 & $\begin{array}{l}\text { Check the absence of female } \\
\text { students frequently during distance } \\
\text { teaching }\end{array}$ & 3.70 & 0.916 & 8 & High \\
\hline 16 & $\begin{array}{l}\text { Investing all the icons equipped with } \\
\text { the classroom screen related to the } \\
\text { virtual classroom }\end{array}$ & 3.70 & 1.106 & 9 & High \\
\hline 3 & $\begin{array}{l}\text { End the electronic lecture on the } \\
\text { specified time and commit to exit } \\
\text { from it last attendees }\end{array}$ & 3.69 & 0.837 & 10 & High \\
\hline 5 & $\begin{array}{l}\text { Commitment in advance to upload } \\
\text { course topics electronically to } \\
\text { facilitate their presentation by } \\
\text { students }\end{array}$ & 3.62 & 0.885 & 11 & medium \\
\hline 18 & $\begin{array}{l}\text { Ensure that a time is set for the } \\
\text { students to discuss a specific topic in }\end{array}$ & 3.56 & 1.140 & 12 & medium \\
\hline
\end{tabular}




\begin{tabular}{|c|c|c|c|c|c|}
\hline & $\begin{array}{l}\text { the discussion room during the } \\
\text { remote lecture }\end{array}$ & & & & \\
\hline 15 & $\begin{array}{l}\text { Considering that the electronic } \\
\text { lecture is to implement the } \\
\text { important objectives with a long time }\end{array}$ & 3.41 & 0.975 & 13 & medium \\
\hline 11 & $\begin{array}{l}\text { Offer to divide the lecture's time in } \\
\text { front of its students before starting it }\end{array}$ & 3.33 & 1.146 & 14 & medium \\
\hline 22 & $\begin{array}{l}\text { Correcting test answers during the } \\
\text { time of the virtual lecture }\end{array}$ & 2.90 & 1.382 & 15 & medium \\
\hline 24 & $\begin{array}{l}\text { Avoid listening to the students } \\
\text { 'discussion of the topic of the lesson } \\
\text { for fear of wasting the time of the } \\
\text { electronic lecture }\end{array}$ & 2.89 & 1.413 & 16 & medium \\
\hline 25 & $\begin{array}{l}\text { Considering that distance teaching is } \\
\text { a waste of time due to its many } \\
\text { problems }\end{array}$ & 2.86 & 1.393 & 17 & medium \\
\hline 23 & $\begin{array}{l}\text { Spending time in solving students' } \\
\text { problems via the approved } \\
\text { discussion board page in the } \\
\text { electronic system }\end{array}$ & 2.80 & 1.287 & 18 & medium \\
\hline 14 & $\begin{array}{l}\text { Additional virtual classes are held to } \\
\text { end the course with dates other than } \\
\text { the dates set for the lecture }\end{array}$ & 2.66 & 1.335 & 19 & medium \\
\hline 7 & $\begin{array}{l}\text { Asking an assistant faculty member } \\
\text { to give her electronic lecture }\end{array}$ & 2.43 & 1.402 & 20 & medium \\
\hline 13 & $\begin{array}{l}\text { Moving to implement a new unit } \\
\text { before completing the previous unit }\end{array}$ & 2.43 & 1.191 & 21 & medium \\
\hline 17 & $\begin{array}{l}\text { Determine Set office hours via the } \\
\text { zoom platform to view the } \\
\text { requirements of the students for the } \\
\text { course }\end{array}$ & 2.32 & 1.399 & 22 & Low \\
\hline 21 & $\begin{array}{l}\text { Postponing the implementation of } \\
\text { the lecture for another time during } \\
\text { the day of its session }\end{array}$ & 2.20 & 1.295 & 23 & Low \\
\hline
\end{tabular}




\begin{tabular}{|l|l|l|l|l|l|}
\hline 10 & $\begin{array}{l}\text { Spending the electronic lecture time } \\
\text { by talking about topics outside the } \\
\text { lesson framework }\end{array}$ & 2.03 & 0.904 & 24 & Low \\
\hline 9 & $\begin{array}{l}\text { Sometimes apologies for completing } \\
\text { the lecture to accomplish personal } \\
\text { work }\end{array}$ & 2.00 & 1.005 & 25 & Low \\
\hline- & The tool as a whole & $\mathbf{3 . 2 1}$ & $\mathbf{0 . 5 1 2}$ & - & medium \\
\hline
\end{tabular}

It is evident from the results mentioned in the previous table No. (2) that the general arithmetic mean of the respondents of the sample to the paragraphs that measure the degree of commitment of the faculty members in the College of Education in Dalm to time management in light of distance teaching has reached (3.21) with an arithmetic average (0.512) and represents a degree Average rating, and paragraph No. (8) came first (avoiding using the phone during the electronic lecture) with an arithmetic average (4.14), followed by paragraph No. (1) with an arithmetic average (4.11), and paragraph No. (9) came in last place (apology) Sometimes for completing the lecture to accomplish personal work) with a mean (2.00). This result indicates that the subject of distance education is a new topic as a result of the health conditions that the countries of the world are going through, including the Kingdom of Saudi Arabia, and accepting the change in the method of education needs time for the two parties to the educational process (the faculty member and the student), and therefore The degree of commitment of faculty members was medium, The result of the present study is consistent with that of Buzbindir (2019),A the better their time planning and effective use of time, the more their significant and insignificant cyberloafing behavior decreased, and The current study agrees with the Van de Vord \& Pogue (2012) , that teaching face to face generally requires more time per student, but that some aspects of online teaching take much longer per student than face-to-face. Classroom face to face.

The present study disagrees with the outcome of the study by Baker, Evans \& Cung (2019), Students who had the opportunity to schedule their lecture viewing in advance scored about a third of the standard deviation better on the first test than students who were not given the opportunity. These effects are concentrated in students with the fewest self-reported time management skills.

3.2 Results related to the second question: Are there statistically significant differences at the level of significance $(\alpha \leq 0.05)$ in the degree of commitment of faculty members in the College of 
Education in Dalam to time management in light of distance teaching from the viewpoint of college students, according to the variable of the academic department and the academic level?

Table 3. Arithmetic averages and standard deviations to identify differences in the degree of commitment of faculty members in the College of Education in Dalam to time management in light of distance teaching from the viewpoint of college students female according to the variables of the academic department and academic level

\begin{tabular}{|c|c|c|c|c|}
\hline $\begin{array}{l}\text { Academic } \\
\text { section }\end{array}$ & Academic level & $\begin{array}{l}\text { Arithmetic } \\
\text { mean }\end{array}$ & $\begin{array}{l}\text { Standard } \\
\text { deviation }\end{array}$ & The number \\
\hline \multirow{4}{*}{$\begin{array}{l}\text { Department of } \\
\text { Economics }\end{array}$} & level five & 3.03 & 0.065 & 10 \\
\hline & Sixth level & 3.25 & 0.494 & 13 \\
\hline & Seventh level & 2.78 & 0.115 & 4 \\
\hline & Total & 3.10 & 0.379 & 27 \\
\hline \multirow{4}{*}{$\begin{array}{l}\text { Mathematics } \\
\text { department }\end{array}$} & level five & 2.98 & 0.509 & 5 \\
\hline & Sixth level & 3.24 & 0.465 & 14 \\
\hline & Seventh level & 3.12 & 0.456 & 18 \\
\hline & Total & 3.15 & 0.461 & 37 \\
\hline \multirow{4}{*}{$\begin{array}{l}\text { Department of } \\
\text { Islamic Studies }\end{array}$} & level five & 3.68 & 0.000 & 4 \\
\hline & Sixth level & 3.40 & 0.438 & 5 \\
\hline & Seventh level & 2.80 & 0.323 & 4 \\
\hline & Total & 3.30 & 0.475 & 13 \\
\hline \multirow{4}{*}{$\begin{array}{l}\text { the department } \\
\text { of Arabic } \\
\text { language }\end{array}$} & level five & 3.08 & 0.000 & 2 \\
\hline & Sixth level & 2.77 & 0.082 & 8 \\
\hline & Seventh level & 3.82 & 0.625 & 13 \\
\hline & Total & 3.39 & 0.689 & 23 \\
\hline \multirow[t]{3}{*}{ Total } & level five & 3.14 & 0.354 & 21 \\
\hline & Sixth level & 3.17 & 0.459 & 40 \\
\hline & Seventh level & 3.29 & 0.624 & 39 \\
\hline
\end{tabular}




\begin{tabular}{|l|l|l|l|l|}
\hline & Total & 3.21 & 0.512 & 100 \\
\hline
\end{tabular}

The results of the previous table No. (3) show the existence of apparent differences between the values of the arithmetic averages of the responses of the sample members towards the paragraphs of the dimensions of the study tool according to the variables of the academic department and the academic level, and to determine whether these differences are statistically significant, a dualvariance analysis (Tow Way Anova) was performed. Here are the results:

Table 4. Results of the (Tow Way Anova) to identify the differences in the degree of commitment of faculty members in the College of Education in Dalam to time management in light of distance teaching from the viewpoint of college students female according to the variables of the academic department and academic level.

\begin{tabular}{|l|l|l|l|l|l|}
\hline $\begin{array}{l}\text { The source of } \\
\text { the contrast }\end{array}$ & $\begin{array}{l}\text { Sum of } \\
\text { squares }\end{array}$ & DF & $\begin{array}{l}\text { Average of } \\
\text { squares }\end{array}$ & F value & $\begin{array}{l}\text { Indication } \\
\text { of } f\end{array}$ \\
\hline $\begin{array}{l}\text { Academic } \\
\text { department }\end{array}$ & 1.140 & 3 & 0.380 & 1.462 & 0.230 \\
\hline $\begin{array}{l}\text { Academic } \\
\text { level }\end{array}$ & 0.174 & 2 & 0.087 & 0.335 & 0.716 \\
\hline The error & 24.432 & 94 & 0.260 & & \\
\hline Total & 25.976 & 99 & & & \\
\hline
\end{tabular}

The results of the previous table No. (4) indicate that there are no statistically significant differences at the level of significance $(\alpha \leq 0.05)$ in the degree of commitment of the faculty members in the College of Education in Dalm to time management in light of distance teaching from the viewpoint of the college students according to two variables: (Academic section And the academic level) depending on the decrease in the calculated (F) values appearing in the table, which are respectively (1.462 and 0.335$)$, which are not statistically significant at the level of significance $(\alpha \leq 0.05)$.This result means that the students femaleagree in opinion about the degree of commitment of faculty members from various scientific disciplines and academic levels, The present finding is in agreement with the study of Oyarzun, Martin, \& Pogue (2012). The relationship between demographics and faculty strategies showed that receiving training for teaching online influenced faculty perceptions of technical time management strategies. 


\section{CONCLUSION}

1. The study found that the general arithmetic mean of the respondents 'answers to the paragraphs that measure the degree of commitment of the faculty members in the College of Education in Dalam to time management in the light of distance teaching reached (3.21) and represents an medium average grade

2. The absence of statistically significant differences at the level of significance $(\alpha \leq 0.05)$ in the degree of commitment of faculty members in the College of Education in Dalam to time management in light of distance teaching from the viewpoint of the college students female according to the two variables: (academic department and academic level).

\section{RECOMMENDATIONS}

Depending on the previous results, the study includes the following recommendations:

1. Creating and developing distance learning platforms and encouraging faculty members to adhere to distance education.

2. The necessity to specify dates for giving lectures at the university's headquarters and at dates determined by the university according to a specific time schedule to increase the degree of commitment of faculty members to teaching remotely.

3. Conducting more scientific studies similar to the subject of the current study on societies other than those dealt with in the current study in order to benefit from its findings and generalize its recommendations.

\section{ACKNOWLEDGMENTS}

This research publication was supported by Deanship of Scientific Research, Prince Sattam Bin Abdulaziz University, Alkharj, Saudi Arabia.

\section{REFERENCES}

Aeon, B., \& Aguinis, H. (2017). It's about time: New perspectives and insights on time management. Academy of Management Perspectives, 31(4), 309 330. https ://doi.org/10.5465/amp.2016.0166

Akar, H. (2018). Meta-Analysis Study on Organizational Outcomes of Ethical Leadership. Educational Policy Analysis and Strategic Research, 13(4), 6-25. 
Baker, R., Evans, B., Li, Q., \& Cung, B. (2019). Does inducing students to schedule lecture watching in online classes improve their academic performance? An experimental analysis of a time management intervention. Research in Higher Education, 60(4), 521-552.

Beattie, G., Laliberté, J. P., Michaud-Leclerc, C., \& Oreopoulos, P. (2017). What sets college thrivers and

divers apart? A contrast in study habits, attitudes, and mental health. National Bureau of Economic Research Working Paper No. 23588. https://doi.org/10.3386/w23588

Bozbayindir, F. (2019). The Relationship between the Time Management Skills and Cyberloafing Behavior of School Administrators: A Quantitative Analysis. Educational Policy Analysis and Strategic Research, 14(3), 178-199

Bülbül, A. (2014). Time Management for Health Care Workers (Kırklareli Sample). (Unpublished master's thesis). Beykent University, Institute of Social Sciences, Istanbul.

Çelebi, K. (2017). An Empirical Study on the Positive Contribution of Efficient Time Management to Productivity Perception in Service Sector: A Hospital Case (Unpublished master's thesis). Çağ University, Institute of Social Sciences, Mersin.

Dias, A. F. (2020). Trans* escrevivências as a pedagogical power. Journal of Research and Knowledge Spreading, 1(1): 1-17.

Lloyd, S. A., Byrne, M. M., \& McCoy, T. S. (2012). Faculty-perceived barriers of online education. Journal of Online Learning and Teaching, 8 (1). Retrieved from https://jolt.merlot.org/vol8no1/abstracts.htm

Paraskeva, J. M. (2016). "Brutti, Sporchi \& Cattivi": Towards a Non-Abyssal Curriculum. Revista Tempos Espaços Em Educação, 9(18), 75-90.

Heckler, V. et al. ECInvestigation with experimental practical activities in training geographically distant teachers. Journal of Research and Knowledge Spreading, 1(1): 1-15.

Oyarzun, B., Martin, F., \& Moore, R. L. (2020). Time management matters: Online faculty perceptions of helpfulness of time management strategies. Distance Education, 41(1), 106-127, https://doi.org/10.1080/01587919.2020.1724773

Van de Vord, R., \& Pogue, K. (2012). Teaching time investment: Does online really take more time than face-to-face?. International Review of Research in Open and Distributed Learning, 13(3), 132146, https://doi.org/10.19173/irrodl.v13i3.1190

Yurdagül, S. (2016). Time management fort he individuals who actively do sports demographic differences ( Elazig province example). (Unpublished master's thesis). FIrat University, Institute of Health Sciences, Elazığ. 
Thikryat Jibril Qaralleh

Professor at the Department of Educational Sciences, College of Education AlDelam, Prince Sattam bin Abdulaziz University, AlKharj, Saudi Arabia.

Email:ti.qaralleh@psau.edu.sa

ORCID: https://orcid.org/0000-0003-2552-4815 